promoted Whitman and his work and helped to bring Leaves of Grass to the attention of British readers and critics alike. ${ }^{13}$ Also, when Walt was fired from his position in the Interior Department by Secretary Harlan, the Commonwealth ran an editorial in its February 3, 1866, issue titled "Secretary Harlan Playing Cato the Censor," which condemned the Secretary's actions. Three weeks later Sanborn published a long and positive critique of Drum-Taps in Commonwealth. Gay Wilson Allen suggests that Sanborn undoubtedly had a particular interest in the subject matter of Drum-Taps because of his earlier knowledge of Whitman's extensive hospital work. ${ }^{14}$ Obviously, for some at least, this gentle lover of suffering humanity would always hold a special place in their hearts.

University of Scranton

LEN Gougeon

\title{
NOTES
}

1 Gay Wilson Allen, The Solitary Singer: A Critical Biography of Walt Whitman (New York: Macmillan, 1955), 281-283.

2 Justin Kaplan, Walt Whitman, A Life (New York: Bantam, 1980), 275.

3 Allen, 290.

4 Quoted in Florence Bernstein Freedman, William Douglas O'Connor: Walt Whitman's Chosen Knight (Athens: University of Ohio Press, 1985), 101.

5 Jerome Loving, Walt Whitman's Champion: William Douglas O'Connor (College Station: Texas A\&M University Press, 1978), 35.

6 See Allen, 240, and Kaplan, 254-255.

7 Franklin Sanborn, "Whitman and Emerson," in Transcendental and Literary New England, ed. Kenneth Walter Cameron (Hartford: Transcendental Books, 1975), 202203.

8 The Correspondence, ed. Edwin Haviland Miller (New York: New York University Press, 1961), 1:122-123.

9 Autobiography, Memories and Experiences of Moncure Daniel Conway (Boston: Houghton, Mifflin, 1904), 1:369.

10 Franklin Sanborn, Recollections of Seventy Years (Boston: Gorham Press, 1909), 264-265.

11 Allen, 368.

12 Correspondence, 1:122-123n.

13 Correspondence, 1:14.

14 Allen, 368.

\section{WALT WHITMAN AND WILLIAM COWPER: A BORROWING}

On Walt Whitman's reading in British poetry Floyd Stovall observes that Whitman hardly cared for early or late neoclassical poets. Citing a passage from 
Specimen Days, Stovall shows us how Milton, Young, Gray, Beattie, and Collins failed to enthuse Whitman in $1879 .{ }^{1}$ However, neither Stovall nor any other critic has told us what, if anything, the British poet William Cowper (1731-1800) meant to Whitman. The poet's own writings, to the best of my knowledge, do not mention Cowper except for once in a Brooklyn Daily Eagle editorial. The reference there, of course, is not to the poetry of Cowper but to his political persuasion. Whitman clubs Cowper with Johnson to damn him for his servile loyalty to monarchy, a system abhorrent to the author of Democratic Vistas. "[M] any of the most literary men of England," writes Whitman, "are the advocates of doctrines that in such a land as ours are the rankest and foulest poison,-Cowper teaches blind loyalty to the 'divine right of kings'-Johnson was a burly aristocrat-and many more of that age were the scorners of the common people, and pour adulation on the shrine of 'Toryism.' "2 Given Whitman's apparent indifference to Cowper, it is indeed surprising that a line in "Passage to India" is an all but verbatim borrowing of a line from "On the Receipt of My Mother's Picture Out of Norfolk."

In the concluding lines of Section 8 of "Passage to India," we recall, the Soul forges ahead like a ship and finally confronts God:

Reckoning ahead O soul, when thou, the time achiev'd,

The seas all cross'd, weather'd the capes, the voyage done,

Surrounded, copest, frontest God, yieldest, the aim attain'd

As fill'd with friendship, love complete. . . . (11. 219-222, emphasis added $)^{3}$

In Cowper's poem, the verse is as magisterial, the image of the ship in triumphant advance as vivid, as in "Passage to India." The Soul in Cowper is the poet's dead mother:

Thou, as a gallant bark from Albion's coast (The storms all weathered and the ocean crossed)

Shoots into port at some well-havened isle, There sits quiescent on the floods that show Her beauteous form reflected clear below, While airs impregnated with incense play

Around her, fanning light her streamers gay;

So thou, with sails how swift! hast reached the shore. . . (11. 88-96, emphasis added $)^{4}$

The locative absolutes in parentheses in Cowper and Whitman not only point up the stages in the Soul-ship's passage braving nature's heavy odds but anticipate its happy arrival at a heavenly port. Whitman, a few lines earlier, and Cowper, a few lines later, in their respective poems grieve inconsolably over their distance from heaven. Each poet compares his station with that of his ideal Soul who has anchored itself finally in God. The two passages are worth reading in conjunction:

How should I think, how breathe a single breath, how speak, if, out of myself, I could not launch, to those, superior universes?

Swiftly I shrivel at the thought of God, 
At Nature and its wonders, Time and Space and Death,

But that I, turning, call to thee O Soul . . . . (Whitman, 11. 204-208)

But me, scarce hoping to attain that rest,

Always from port withheld, always distressed-

Me howling blasts drive devious, tempest-tost,

Sails ripped, seams opening wide, and compass lost, . . .

Sets me more distant from a prosperous course. (Cowper, 11. 100-105)

Although it is tempting to suggest that Whitman owed the topos of the Soul-ship's journey to Cowper, it is safe to assume that its source probably lies elsewhere: the Bhagavad Gita, Shakespeare, or even Shelley. What seems very probable is the way Cowper's parenthetical aside dictated the phrases and rhythm of line 220 of "Passage to India." This granted, we need not strain too hard to hear further echoes of Cowper's moving tribute to his mother in Whitman's apostrophe to his Soul:

What love than thine and ours could wider amplify?

What aspirations, wishes, outvie thine and ours $\mathrm{O}$ soul?

What dreams of the ideal? What plans of purity, perfection, strength?

What cheerful willingness for others' sake to give up all?

For others' sake to suffer all? (11.214-218)

This small borrowing may initially seem little more than an interesting and idiosyncratic triviality, but it underscores a larger point about "Passage to India." While Whitman in the 1840s dismissed Cowper's aristocratic tendencies, he had come to embrace, by the late 1860s when he was working on "Passage," a more conventional logocentrism, and he was much more inclined to give credence to the agency which would allow for the "divine right of kings." It therefore may not be so surprising after all that Whitman at this point in his career turned to Cowper. As Arthur Golden has conclusively demonstrated, "Passage" is a poem that Whitman patched together from disparate, independently conceived poems, and it thus fails for its very artificiality, its lack of spontaneity. ${ }^{5}$ We can now add to this sense of a lack of originality the evidence that Whitman was borrowing not only from himself, but from another poet as well.

University of Hyderabad, India

K. NaRayana Chandran

\section{NOTES}

1 Floyd Stovall, The Foreground of Leaves of Grass (Charlottesville: University Press of Virginia, 1974), 235.

2 Walt Whitman, “'Home' Literature," in The Gathering of the Forces (New York: G. P. Putnam, 1920), 2:243.

3 The "Passage to India" citations are from Leaves of Grass, ed. Harold W. Blodgett and Sculley Bradley (New York: New York University Press, 1965), 411-421. The line numbers appear in parentheses. 
4 "On the Receipt of My Mother's Picture Out of Norfolk" citations are from Cowper's Shorter Poems, ed. W. T. Webb (London: Macmillan, 1896), 38-41. The line numbers appear in parentheses.

5 "Passage to Less than India: Structure and Meaning in Whitman's 'Passage to India," " PMLA 88 (October 1973), 1095-1103.

\section{THE WHITMAN RECORDING}

One event at the recent Whitman Centennial Conference held at The University of Iowa from March 26-29, 1992, was the playing of a tape-recording of what may be an 1889 or 1890 wax-cylinder recording of Walt Whitman reading four lines of his late poem "America" ("Centre of equal daughters, equal sons"). It turns out that this recording has been available for some time, but very few people knew about it. I had long heard rumors that such a recording existed - a number of people had told me they vaguely recalled hearing it in the early 1950s - but the first substantiation came when Professor Larry Griffin of Midland College in Texas submitted an essay to the Walt Whitman Quarterly Review last year. Griffin's essay, "Walt Whitman's Voice," appeared in the Winter 1992 issue of WWQR; in a note to his essay, Griffin mentioned the existence of a cassette recording of a program that contained Whitman's voice; the cassette had been available for years in the Midland College Library.

This cassette, it turns out, contained a recording of a radio broadcast of a program narrated by Leon Pearson, a well-known NBC newsman (and brother of Drew Pearson). The program was broadcast on NBC Radio in 1951, part of a series called "Yesterday, Today, and Tomorrow." In the program, Pearson introduces the Whitman recording by saying that the cylinder, from the "remarkable Roscoe Haley Collection in New York," was badly damaged when NBC engineers received it, but that they were eventually able to retrieve the four lines of "America." Roscoe Haley, born in Tennessee in 1889, was an elevator operator who lived in New York City until his death in 1982; an eccentric collector, his Manhattan apartment was jammed full of recordings, books, and papers. Apparently, after the initial broadcast, Haley's Whitman recording faded into near-oblivion.

The rediscovery of the Whitman recording this year generated a good deal of media attention. William Grimes wrote a substantial piece about the recording in the New York Times (March 16, 1992), and it was featured on National Public Radio's “Morning Edition" (March 20, 1992) as well as CBS television's "Sunday Morning" (April 19, 1992). Associated Press stories about the recording were reprinted across the country, and many radio and television stations in the United States and Canada carried reports of the find. A letter dated February 14, 1889, and signed by Thomas Edison, expressing his interest in trying to "obtain a phonogram from the poet Whitman," turned up in the files of the Edison Institute. Edison's letter is addressed to his associate Jesse H. Lippincott; it is in response to a letter Edison had received from Whitman's Boston admirer, the journalist Sylvester Baxter, who had written to Edison urging him to record Whitman's voice. So far, no corroborating evidence has been found among Whitman's papers or those of the poet's friends and associates. 